Archived version from NCDOCKS Institutional Repository http://libres.uncg.edu/ir/asu/

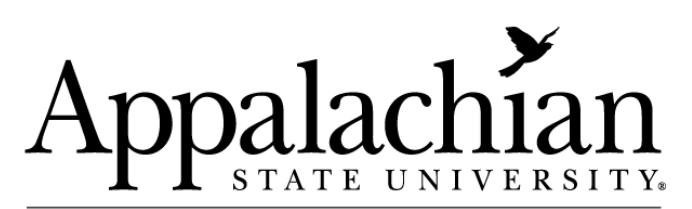

B O O N E, NORTH CAROLIN A

Robinson, Matthew B. (2000). The Construction and Reinforcement of Myths of Race and Crime, Journal of Contemporary Criminal Justice 16, 2:

133-156. ISSN: 1043-9862 


\title{
The Construction and Reinforcement of Myths of Race and Crime
}

\author{
MATTHEW ROBINSON \\ Appalachian State University
}

\begin{abstract}
Much of what we know about crime is myth. Myths are falsehoods that have become accepted as truth because they have been told and retold over time. Many myths of crime revolve around race. This article documents how myths of crime associated with race are created and reinforced through the criminal justice process and the media. The examination begins with the process of lawmaking, demonstrating how American criminal law creates biases against particular groups and benefits others by creating myths about race and crime. The article then analyzes how por- trayal of crime in the mass media and activities of law enforcement, courts, and corrections reinforce myths of race and crime. A model of myth creation and reinforcement is presented, and implications of the model for the American criminal justice system and larger society are discussed.
\end{abstract}

A myth is a falsehood that becomes accepted as truth because it is told and retold over time. Crime myths are distorted conceptions of crimerelated issues that have deviated from the truth because of debate and discussion through public forums and private conversations. Myths are not true, except in the minds of their believers (Kappeler, Blumberg, \& Pottem, 1996). The main problem associated with crime myths is that they "support and maintain prevailing views of crime, criminals, and the criminal justice system, strengthening the tendency to rely on established conceptions of crime and justice" (Kappeler et al., 1996, p. 3). Typically, crime myths are built around particular groups in society, usually lower-class minority males. The creation and reinforcement of these myths, and their consequences, are the focus of this article. 
One of the most prevalent myths in U.S. society, entrenched in the minds of virtually everyone, is that minorities commit more crime than Whites. Even the Reverend Jesse Jackson, a civil rights leader, founder of the Rainbow Coalition, and soldier in the fight for equality for all, subscribes to this myth. Jackson once said, "There is nothing more painful for me at this stage in my life than to walk down the street and hear footsteps and start to think about robbery and then to look around and see if it's somebody White and feel relieved" (Kennedy, 1997,p. 15). The truth is, people fear African Americans and other minorities and perceive them to pose significant threats to their personal safety (Hurwitz \& Peffley, 1997; Miethe, 1995; Peffley \& Hurwitz, 1997; Skogan, 1995; St.John \& Heald-Moore, 1996). Blackness, in particular, is treated as a sign for increased risk of criminality (Kennedy, 1997, p. 387). As illustrated by the Jesse Jackson example above, this is a normal phenomenon that results not from individual racism or bias, but rather from deep-seated, institutionalized myths of race and crime that are created and reinforced through the criminal justice process and the media.

Race plays such a role in the criminal justice process, resulting in overwhelming disparities throughout the system and, thus, Unequal Justice (Mann, 1993), and an unappealing The Color of Justice (Walker, Spohn, \& Delone, 1996; see also Skolnick, l 998a, l 998b). The result for African American males has been Lock 'Em Up and Throw Away the Key (Mauer, 1998) because of what some call a "search and destroy" mission by the criminal justice system (Miller, 1997). Although racial disparity does not necessarily imply racial discrimination, if the disparity is harmful, the intent is not important (Kennedy, 1997). The focus of this discussion is how criminal justice disparities that negatively affect African Americans arise and become stable through the process of myth creation and reinforcement, a process that creates "a racial ideology of crime that sustains continued White domination of Blacks in the guise of crime control" (Roberts, 1993, in Kennedy, 1997, p. 27).

\section{THE MYTH PROCESS}

Myths of race and crime start at the law-making stage. Such myths are reinforced through the interactions of each institution represented in Figure 1.As the police, courts, and corrections personnel enforce and carry out criminal laws, and as these activities are broadcast by the media, myths rooted in criminal law are reinforced or strengthened. To illustrate how myths of race and crime come into existence and persist over time, each stage of this myth process will be examined. 
The process starts with the law-making stage, because the law dictates what police, courts, and corrections do-that is, the criminal law sets forth what is crime and what sanctions can follow from illegal behaviorstherefore, activities of police, courts, and corrections personnel all directly stem from the law. Criminal justice activity is also regularly broadcasted and at times even celebrated by the mass media (e.g., O.J. Simpson case). Once the law is in place, police enforce the criminal law by responding to calls for service, investigating alleged crimes, and apprehending suspects. Courts determine guilt of suspects and impose some form(s) of criminal sanction on the legally guilty. Correctional facilities and programs carry out the sanctions of the courts and administer punishment to sentenced offenders. The media informs the public about the passage of new laws. It also broadcasts stories about law enforcement investigations and arrests of suspects, criminal trials and convictions of offenders, and correctional commitments, escapes, and recent executions. The institutions represented in Figure 1 thereby reinforce the validity of the law and all myths rooted in that law, hence the arrows all return to the law in Figure 1. As the law is reinforced by criminal justice operations, myths of crime are created based on who is processed through the system. One only need look at arrest, conviction, and incarceration statistics to see who is a criminal and therefore dangerous.

The creation and reinforcement of myths of race and crime is a cyclical, systemic process. The main elements of this process include legislating crime, media portrayals of crime, and the activities of agencies of criminal justice in America. In examining this process, three key myths of race and crime are illustrated and dispelled. Myth 1: The label of crime is a function of what is most harmful to society; Myth 2: African Americans commit more crime than other groups in society; and Myth 3: The criminal justice system is fair or unbiased. The examination begins with legislation, including law makers, voters, and special interests.

\section{Lawmakers, Vters, and Special Interests}

Myths of race and crime start when behaviors are legislated as criminal. To the degree that lawmakers are representative of all of society, it is likely that laws will represent all people in society. Table 1 shows demographic characteristics of state and federal legislators and the U.S. population. At the federal level (106th Congress, 1999 to 2001), the U.S. House of Representatives has 39 African Americans (9\%) and 63 minorities (14\%) overall. The U.S. Senate has no African Americans and 3 minorities (3\%). Therefore, the majority of legislators at the federal level are White, including $86 \%$ of Representatives and $97 \%$ of Senators. There are 58 women in the U.S. House (13\%) and 9 women in the U.S. Senate (9\%). The majority of federal legislators are men: 


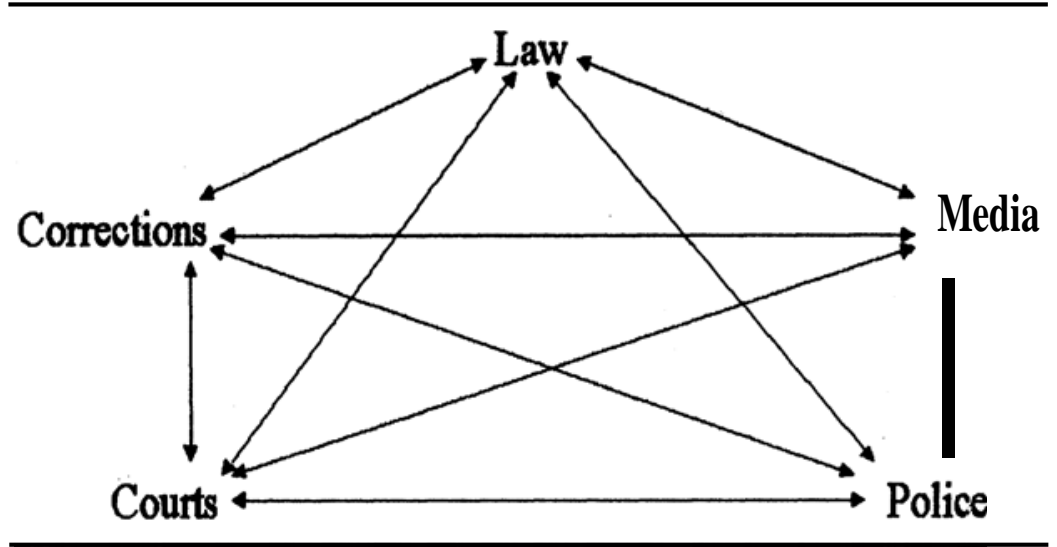

Figure 1: The Myth Process: Creation and Reinforcement

$87 \%$ and $91 \%$ of House and Senate members, respectively. The average age of federal legislators in the House is 53, 58 in the Senate, and 54 years old overall (Congressional Quarterly, 1999).

At the state level, there are 388 African Americans (7\%) in Houses of Representatives and 123 African Americans (6\%) in Senates. Therefore, approximately $90 \%$ of legislators at the state level are White. In terms of gender, $22 \%$ of state legislators are women, making the majority of federal legislators men. The average age of state legislators is 49.4 years (see Table 1). In the general population, the median age is 34.6 years, making legislators at both federal and state levels older on average than the general U.S. population. Although $51 \%$ of U.S. citizens are women, they are underrepresented as law makers. The U.S. citizenry is approximately $86 \%$ White and almost 13\% African American: Whites are overrepresented as law makers and African Americans are underrepresented (U.S. Census, 1996).

It can be concluded that lawmakers are not representative of the general population in terms of demographic characteristics such as race. Among all federal, state, and local elected officials, African Americans hold only 1.6\% of the seats, despite accounting for $12.7 \%$ of the general population (Joint Center for Political and Economic Studies, 1993).

Elected representatives may still represent the voter, but most people do not vote. For example, $63 \%$ of people 18 years old or older are registered to vote and only 45\% voted in the 1996 elections (U.S. Census, 1999). Voters are not representative of the general population demographically, either. The majority of voters are White (82\%), and only $10 \%$ of voters are African Americans. The highest percentage of voters come from specific subgroups 
TABLE 1

Demographic Characteristics of Legislators and the General U.S.Population

\begin{tabular}{|c|c|c|c|}
\hline & U.S. Population ${ }^{\circ}$ & U.S. Congresi & State Legislators \\
\hline Median age (in years) & 34.6 & 54.0 & $49.4 \mathrm{c}$ \\
\hline Percentage women & 51.1 & 12.5 & $22.0 \mathrm{~d}$ \\
\hline Percentage White & 82.8 & 87.7 & $90.0^{\circ}$ \\
\hline Percentage Black & 12.7 & 7.3 & $6.9 \mathrm{r}$ \\
\hline
\end{tabular}

a. U.S. Census, July 1, 1996, estimate.

b. Congressional Quarterly, January 9, 1999.

c. Based on an estimate from a study of 900 state lawmakers from 16 states (Woo, 1994).

d. National Conference on State Legislators, 1999.

e. Based on an estimate from National Conference on State Legislators, 1999.

f. Black Elected Officials: A National Roster, 1993.

in society. For example, in 1996, 58\% of voters were older than age 45; $64 \%$ of people had 4 or more years of college education; and $64 \%$ were government employees. Voting is lowest in the South (41\%), where poverty and minority residence are very high (U.S. Census, 1999).

Because most people do not vote, elected representatives enact laws that address the concerns of certain groups of voters. By extension, the criminal law serves special interests other than those of the voter. Pure conflict theory holds that the criminal law results as a formal means to settle unresolved conflicts between various groups who disagree about what is normal and acceptable behavior: "The dominant groups can see to it that their particular definitions of normality or deviance will become enacted as law, ensconced in public policy, and protected by the operation of the criminal justice system" (Akers, 1996, p. 142). The criminal law is created by and protective of those who wield economic, political, and social power (Bernard, 1983; Chambliss \& Seidman, 1971, 1982; Quinney, 1969, 1970). That is, law on the books, criminal justice system activity, and media reporting that result, serve very limited interests. The following is noted by Vold (1958):

The whole political process of law making, law breaking, and law enforcement becomes a direct reflection of deep-seated and fundamental conflicts between interest groups and their more general struggles for the control of the police power of the state. Those who produce legislative majorities win control over the police power and dominate the policies that decide who is likely to be involved in violation of the law. (pp. 208209)

Pure conflict theory is less well suited to account for law-making activities than pluralistic conflict models because, in the latter, groups other than powerful elites are involved in the codification of criminal law (Castellano \& 
McGarrell, 1991). The general public makes demands, and events such as media reporting and 40,000 lobbying actions of more than a dozen interest groups affect legislation (Brunk \& Wilson, 1991; also see Hagan, 1989; McGarrell, 1993; Walker et al., 1996; Wright, 1993). This leaves the voter with the realization that his or her vote, letter, phone call, fax, e-mail, or visit carries relatively little weight in a political process driven by money. For example, national political parties raised more than \$193 million in soft money for 1997 to 1998 , more than twice as much as in 1993 to 1994 . A leading donor to political parties is "big tobacco." In 1997to 1998 alone, 20 tobacco donors gave nearly $\$ 1.9$ million to Democrats, with $\$ 900,000$ coming from Philip Morris, and 29 donors gave almost $\$ 9.7$ million to Republicans, with \$4.3 million coming from Philip Morris (Common Cause, 1999; Salant, 1999). Not surprisingly, in June 1998, Senate Republicans defeated legislation that would have raised more than $\$ 500$ billion over 25 years through a $\$ 1.10$ tax increase on a pack of cigarettes (Common Cause, 1999; Salant, 1999).Meanwhile, the public, $75 \%$ of which are not smokers, suffers tremendous harms as a result of tobacco use. Given the harmfulness of this legal drug (Robinson, 1998), tobacco executives have avoided criminal convictions for their negligent and reckless behaviors, even in the wake of increased realization of industry deviance and deception.

Myth 1: The label of crime is a function of what is most harmful to society. The tobacco example dispels the first myth of race and crime: The label of crime is a function of what is most harmful to society. There is considerable evidence that "white-collar" crimes (Sutherland, l 977a, l 977b), "elite deviance" (Simon \& Eitzen, 1993), "white-collar deviance" (Simon \& Hagan, 1999), "corporate violence" (Frank \& Lynch, 1992), and those "crimes by any other name" (Reiman, 1996) committed by our "trusted criminals" (Friedrichs, 1996) cause more physical and property damage than all eight serious crimes combined. Tobacco use kills more people $(420,000)$ than murder $(22,500)$. It causes more financial loss $(\$ 50$ billion in direct health care costs) than all street crime combined (\$25 billion) (Robinson, 1998). There are other harms associated with legal acts and "crimes" that are not considered serious or worthy of criminal justice and media attention, which illustrate that the label of crime is not reserved for the most harmful acts in society. Frank and Lynch (1992, pp. 1-11) have documented the costs of physical damage to individuals and society by deadly pollutants, preventable work- related accidents, occupational diseases and deaths, and faulty consumer products. Reiman (1990, pp. 5863) reported the injuries and deaths of Americans caused by hazardous working conditions. Simon and Eitzen (1993, pp. 49-73, 113-114, 121156) cited cases of fraud by companies in the United States and trace resulting harms of savings and loan scandals and tax breaks 
given exclusively to the rich. They also documented the dangers associated with unsafe products, unsafe working conditions, and food products. Friedrichs (1995, pp. 70-88) showed the harms associated with corporate violence against the public, consumers, and workers, and illustrated harms resulting from fraud, tax evasion, price fixing, price gouging, and false advertising. Weisburd and Schlegel (1992, pp. 22-38) have documented the nature and extent of antitrust violations, multiple types of fraud, bribery, tax violations, and embezzlement. Rosoff, Pontell, and Tillman's (1998) discussion of medical crime and computer crime demonstrate the cold, calculated acts of individuals and corporations that result in mindboggling financial and physical harms on an unsuspecting public.

Given that these acts are disproportionately committed by wealthier Whites, the effects of the first myth on minorities, particularly African Americans, is tremendous. Whereas African Americans are rounded up for street crimes, particularly drug crimes, white-collar and corporate criminals walk away unscathed or with a slap on the wrist (Reiman, 1996). This is due to the criminal law, which does not usually label acts of wealthier Whites as crimes. When the acts are labeled, they are not considered serious. In defining what is bad, evil, wrong, harmful, and criminal, the criminal law thus creates myths of crime. The myths cause people to view certain acts as most serious and harmful, even though they are not, and produce fear of certain people and not others who pose even greater threats. In essence, the reaction in part is to harmful acts and, in part, to color and class, rather than merely to harmful conduct (Kennedy, 1997, p. 390). Legislators, because of "malign neglect" toward street crime, pass criminal laws that protect their own interests (Blakemore, 1998; Reiman, 1996). Once the law is in place, criminal justice system activity and media reporting serve to reinforce myths of race and crime.

\section{Media Activity}

Media reporting reinforces the validity of law and the myths, of what is a crime and who is a criminal, inherent within the law. In its broadcasts and editorials, the news media alerts and alarms the public and lawmakers about important events and issues (Castellano \& McGarrell, 1991; Hollinger \& Lanza-Kaduce, 1988). "Media socialize the entire population, mainstream and minority, young and old by the way they depict and discuss minorities" (Chaffee \& German, 1998, p. 311; Reed, 1993) and creates fear through "crime time news" (Cohen \& Solomon, 1994; Livingston, 1994). "The kind of coverage, positive or negative, may also impact the nature of treatment, beneficial or negative, accorded to minorities in the political system" (Chaffee \& German, 1998,p. 312). Overall, positive minority views are lacking 
in media portrayals and African Americans receive most minority- related news coverage. This is detrimental to African Americans, given the biases against minorities in newspaper reports of crime (DeLouth \& Woods, 1996).

Although the media may question a particular enforcement (e.g., the vicious beating of Rodney King captured on video tape), they rarely ever challenge the legal institution as a whole (Reiman, 1996). Some events (e.g., Willie Horton's crimes after he was released early on a prison furlough) have been used by politicians through the media to reinforce a need for new laws that crack down even tougher on street crimes and poor minorities. Meanwhile, media coverage is biased toward violence at the street level (Chiricos, 1995; Kooistra \& Mahoney, Jr., 1999), particularly the rarest and "most egregious examples" of crime (Blakemore, 1998, p. 3). For example, between 1992 and 1993, major network evening news coverage of homicide tripled although homicide rates remained unchanged, and from 1993 to 1996, major network news increased coverage of homicide 721\% (National Center on Institutions and Alternatives, 1999a). Television news generally shows violence at a rate much higher than its incidence in society would seem tojustify (Newman, 1990). As the youngest children grow up watching an average of more than 25 hours of television per week (Centerwall, 1992) and a very large percentage of what is being watched is crime-related television (Bohm, 1986; Newman, 1990), it is not surprising how myths about race and crime become stable over time. The story is the same in newspapers and magazines, where most crime coverage is violent or sensational in nature (Marsh, 1991). As a result, 'the media have the ability, indirectly at least, to manipulate the fear of crime" (Tunnell, 1992, p. 300). Fear reinforces mythology, causing citizens to avoid and police to apprehend people who are perceived as posing the greatest threats to our well-being (Culverson, 1998; Rome, 1998).

The most popular entertainment shows on television recently have included Homicide, Murder She Wrote, Matlock, and Law and Order. These shows involve homicides or other violent crimes. Most of the popular news magazine shows usually broadcast crime stories. According to the Media Institute in Washington, DC, television crimes as depicted on popular television shows are more than 10 times as likely to be violent as those in the real world (The Washington Post, 1983). Even leading criminology and criminal justice texts and journals reinforce crime myths by giving scant coverage of anything other than street crime (McGurrin, Fenwick, \& Lynch, 1999). Not surprisingly, even criminology and criminal justice students fail to accurately characterize the relative harms associated with various criminal and non-criminal behaviors (Robinson, 1999). 
Myth 2.African Americans commit more crimes than Whites. Media activity reinforces the myths that most crime is violent and that most people will be victimized by crime. The second myth-African Americans commit more crime than Whites-is also reinforced by the media. Official rates of offending are higher in poor minority communities and for African Americans generally (Kennedy, 1997; Tonry, 1995). The rates cannot explain the drastic disparities in the criminal justice system (Akers, 1996; National Center on Institutions and Alternatives, 1999a). Although selfreport studies show that rates of offending in middle-class minority communities are equivalent to those in the general population (National Center on Institutions and Alternatives, 1999a), poor minorities are being disproportionately targeted by the criminal justice system. The issues of who commits crime and minority overrepresentation are now examined.

Sources of crime data include the Uniform Crime Reports (UCR), National Criminal Victimization Survey (NCVS), and self-report studies. Whereas the UCR is a measure of crimes known to the police, crimes cleared by arrest, and the number of arrests, the NCVS is a measure of self-reported victimizations. These victimizations include crimes reported to the police and crimes not reported to the police. Reliance on the UCR and other official statistics to dis- cover offender characteristics is flawed and can create misconceptions about who is dangerous and who should be feared. According to Miller (1997, p. 29), "Relying on 'experience' emanating from the justice system is dicey even in the best of circumstances. Its rituals and procedures distort social realities and feed stereotypes at virtually every step." The UCR is a more valid measure of police experience than crime because it measures the behavior of police rather than criminal offenders; therefore, it is not surprising that more than 4 of every 100 individuals arrested for felonies are not prosecuted or their cases are dismissed at first appearance (U.S. Department of Justice, 1987; in Miller, 1997).UCR arrest statistics tend to create myths about who is dangerous and guilty. Relying on arrest statistics only to develop composites of dangerous classes would not produce an accurate picture of those that threaten us most.

The NCVS is generally considered to be a more valid measure of criminal behavior than the UCR. It shows that victims report a higher percentage of African American victimizations than is expected given their percentage in the population (Kennedy, 1997. p. 23). The observed differences cannot account for the disparities in official arrest, conviction, and incarceration statistics. Self-report studies provide unique insight into criminal behavior by assessing the degree to which respondents admit to engaging in criminal behaviors. Self-report studies address the disparities found in official criminal 
justice statistics such as the UCR (Pope, 1979). The UCR suggests that African Americans commit a disproportionate amount of crime because they are more likely to get arrested by the police, but self-report studies do not show such patterns.

Early self-report studies showed little or no differences in self-reported delinquent and criminal behavior between different groups (Tittle \& Villemez, 1977; Tittle, Villemez, \& Smith, 1978). Because these studies typically assessed minor acts of delinquency, more recent studies assess more serious criminal behaviors (Elliott \& Ageton, 1980; Hindelang, Hirschi, \& Weis, 1980; Thornberry \& Farnworth, 1982). According to Tittle and Meier (1990), studies assessing relationships between social class and crime show "mixed results." According to Akers (1996, p. 127), "Self-report studies find class and race variations in criminal and delinquent behavior, but they are not as great as class and race differences in officially arrested, convicted, and/or imprisoned populations ." Thus, when unemployed citizens are disproportionately found in incarcerated populations (Chiricos, 1991), it is not likely due to their increased involvement with criminal behavior. Nor can the overrepresentation of African Americans in the criminal justice system be explained by their higher involvement in criminal behavior. There are myths of race and crime that create bias in the criminal justice process in America and that better account for the overrepresentation of African Americans in the criminal justice system.

It should also be reiterated that self-report studies typically assess involvement in street crimes. If studies examined racial and class differences in people who commit other harmful acts (including legal acts), huge differences would be found-specifically, the vast majority of offenders would not be African American or poor. This is a fact that seems to escape those who argue that African Americans commit more crime. The people who end up viewed as criminals depend on what is considered a crime, and that is a function of who makes the law. As discussed previously, criminal is a label generally reserved for people who look very different from law makers and voters.

Myth 3. The criminal justice system is fair. Logically, bias in the law and media coverage bias implies criminal justice system bias because all criminal justice system activity stems from the law and is supported by the media (See Figure 1). The third myth is that the criminal justice system is fair. Some have gone as far as to claim that our criminal justice system depends on inequality to operate (Cole, 1999). Despite some who believe that a racist criminal justice system is a "myth" in itself (Eubanks, 1987), the U.S. criminal justice system is biased against particular groups, including African Americans and the poor. An unfair criminal justice system begins with the law and continues with the police; after the law is created, the job of enforcing the law falls on 
the police. If the law is distorted, so too will be police actions. Kennedy (1997) traces the historical unequal enforcement by police to demonstrate how deeply rooted the problem is (Blakemore, 1998). Differential law enforcement does not require bad cops; it only requires bad law, which leads to innocent bias on the part of police.

\section{LawEnforcement}

This kind of innocent bias can come in several ways. First, the very nature of policing entitles officers to use unchecked discretion to make decisions (National Association of Criminal Defense Lawyers, 1996). This discretion allows racial stereotypes and myths of crime to infiltrate police work, resulting in racial disparities in arrests and police use of force (Cole, 1999). Second, police focus on some actions more than others, particularly Part I Index Offenses of the UCR. These crimes are also known as street crime or visible crime. Thus, police arrest people suspected of violating those laws, while virtually ignoring those who cause harms through legal or less serious behaviors. Third, the police may focus on particular types of people because of their own personal experience or that of their institution and profession, which suggests that certain people are more likely to violate the law. This practice of police profiling results in startling disparities in police behavior. For example, although African Americans make up just under $14 \%$ of drivers on the New Jersey Turnpike and 15\% of its speeders, they make up $35 \%$ of those pulled over and $70 \%$ of those arrested (National Center on Institutions and Alternatives, 1999). They are pulled over for DWB or "driving while black" (Kennedy, 1997). Thus, police use race as a proxy for risk so that being young, Black, and male equals probable cause (Gaynes, 1993). This phenomenon is even supported by courts as legitimate when race is used in conjunction with other factors. Part of this perceived "social threat" to communities (Jackson, 1997) results from an honest and unintentional exaggeration of risk on the part of police, but it nevertheless creates significant disparities. "Race-dependent policing erodes the difficult-to-maintain habit of individualizing persons and strengthens the reflex of lumping people together according to gross racial categories" (Kennedy, 1997, p. 157).

Other outcomes of police profiling of particular persons include "a climate of alienation, hostility, social unrest, and violence in the nation's inner cities" and a basic distrust and resentment of the police. Not surprisingly, several studies reflect a lower view or approval of law enforcement and government among African Americans than Whites (Denziger, 1996). In areas where it is the worst, such as Washington, D.C., courses on how to respond if stopped by the police are available to citizens (Miller, 1997, p. 26). Some studies also show that police may overcharge arrestees with crimes they did not commit 
to make some charges stick (Smith, 1990). Some of these arrests and overcharging practices have been found to be racially motivated (Nazario, 1993). Therefore, African American jurors' refusal to convict African Americans charged with violent crimes may suggest that outrage against violent crime victimization may be dwarfed by apathy or hostility toward the justice system (Miller, 1997). Finally, police are disproportionately located in inner cities where poverty rates are highest (Robinson, 1994). In 1997, the average poverty rate in central cities was 18.8 , but 9.0 in suburbs (U.S. Census, 1999). Given that police focus on crimes of the poor, targeting particular threatening populations disproportionately located in inner cites, official statistics that suggest that African Americans commit more than their fair share of criminal behavior are called into serious question. The fact that police typically arrest urban street criminals should not be surprising. UCR arrest rates are 4 to 5 times higher for African Americans older than age 18 than for Whites older than age 18, and 2 to 3 times higher for African Americans younger than age 18than for Whites younger than age 18. Alarmingly, African Americans make up roughly 33\% of arrests in any given year even though they only account for about $13 \%$ of the U.S. population. The percentage of African American arrests is also higher in cities (33\%) than in either suburban communities (22\%) or rural areas (17\%). This is expected given their relative residential placement in inner cities (U.S. Department of Justice, 1997).

\section{Courts}

When citizens are arrested by police, they become clients for the courts. Not surprisingly, court defendants are disproportionately poor. Indigent people who cannot afford their own attorneys comprise up to $60 \%$ of people charged with felonies in the United States (Cole \& Smith, 1998). Characteristics of both federal and state court defendants demonstrate who our system pursues. African Americans make up roughly 27\% of U.S. District Court cases and $48 \%$ of those convicted for felonies in state courts. African Americans are more likely than Whites to have pretrial detention hearings, $49 \%$ and $32 \%$, respectively. They are slightly more likely than Whites, $64 \%$ and $58 \%$, respectively, to be held in pretrial detention than Whites; perhaps, this is because African Americans are less able to afford even modest bails (Miller, 1997). African Americans make up 31\% of persons convicted in federal courts, and are slightly more likely than Whites, $82 \%$ and $77 \%$, respectively, to be incarcerated. Furthermore, African Americans are disproportionately likely to be sentenced under federal sentencing guidelines, $28 \%$ of sentences, with the most pronounced disparity for drugs offenses (U.S. Department of Justice, 1997). 
Many factors explain the disparities, but social class and plea bargaining play significant roles. The poor have no right to equal counsel (Cole, 1999; Reiman, 1996). The average public defender has approximately 2,000 cases a year to handle (Cole \& Smith, 1998), meaning she or he has no time to investigate the facts of a case and put on an appropriate and thorough defense. According to Cole (1999), Supreme Court rulings permit and encourage judges to treat inadequate defense attorneys as effective even when they do not investigate the facts of the case, cross-examine crucial witnesses, sleep during testimony, or come to court drunk. Because prosecutors use peremptory challenges to eliminate potential jurors without any explanation, racial minorities are often denied the opportunity to serve on juries (Cole, 1999). Lawyers use race as a proxy to develop peremptory challenges, in part because of racial myths and stereotypes, in part because courts allow subjective qualifications for jury service, and in part because it simply benefits their cases (Kennedy, 1997).African Americans are simultaneously inhibited from jury service for a variety of other reasons, many intimately related to their social class, social status, and past run-ins with the law (Fukurai, Butler, \& Krooth, 1993).

Because approximately $90 \%$ of felony cases are disposed of through plea bargaining, trials are a rare exception (U.S. Department of Justice, 1997). Plea bargaining is a process driven by large caseloads, understaffed courts, and renewed emphasis on using law enforcement to solve drug use and public order offenses. The result is bias against poor clients, including African

Americans. Some may argue that no person would enter a guilty plea for a crime she or he did not commit. Miller (1997) points out that a poor person charged with a minor crime is guaranteed a longer stay in jail (awaiting a hearing often longer than the likely sentence to be imposed upon conviction through a guilty plea) when she or he does not plead guilty.

At the same time, some court clients are subjected to sentencing laws that are biased. More than half of the states in the United States have passed mandatory sentences laws commonly referred to as "Three Strikes You're Out" laws. These laws usually require offenders to serve a minimum number of years sentence after a third conviction (or sometimes a second or fourth). Harvard Medical School researcher William Brownsberger claims such laws "are wasting prison resources on non-violent, low-level offenders and reducing resources available to lock up violent offenders" (National Center on Institutions and Alternatives, 1999a). The RAND Corporation claims that mechanisms such as drug treatment, parent training, delinquent supervision, and graduation incentives are more cost effective and up to 7 times more effective at reducing recidivism than mandatory prison terms when drug offenses are included in mandatory sentencing, such sentencing laws become a major source of criminal justice bias. Although $13 \%$ of monthly drug users 
are African Americans, they account for $25 \%$ of arrests for drug possession, $55 \%$ of convictions, and $74 \%$ of prison sentences (Mauer \& Huling, 1995). At the federal level, 39\% of crack users are African American and $89 \%$ of people sentenced for federal crack crimes are African American. Throughout the United States, convicted drug offenders are disproportionately lowincome minorities. The impact of sentencing laws on minorities (especially African Americans) is greatest at the federal level. In 1980, the number of federal inmates who were minorities was 8,085 (33\%), but the number increased to 65,000 (64\%) in 1995 (Coalition for Federal Sentencing Reform, 1999). This bias counters the myth that the criminal justice system is fair. It has been suggested that the war on drugs amounts to genocide "because Blacks constitute a disproportionate number of those subjected to arrest, prosecution, and incarceration for illicit drug trafficking" (Meddis, 1993).

In the wars against drugs and violence, federal sentencing has become much more complex. From 1987 to 1998, federal sentencing guidelines increased from 325 to 1,194pages. The federal sentencing grid now contains 258 boxes, and calculations needed to determine the proper sentence occupy a 393 page rule book with 539 pages of appendices. The prosecutor decides what crime to charge and how many counts to charge. Thus, the prosecutor effectively determines the likely sentence. Such concentration of power creates bias in favor of the government and against the client, who is innocent until proven guilty. Only prosecutors can reward suspects for turning state's evidence against other suspects.

The judges have little oversight in the process. For example, $86 \%$ of judges want to modify federal sentencing guidelines to increase their sentencing discretion. A 1992 survey of judges found they believed that only 1 in 4 sentences imposed under guidelines is appropriate (Coalition for Sentencing Reform, 1997). A particularly striking unfair pattern is the 100:1ratio in sentences for crack cocaine and powder cocaine (U.S. Sentencing Commission, 1995). To receive a mandatory sentence of 5 years' imprisonment, a person must be convicted of 500 grams of powder cocaine or 5 grams of crack cocaine (The Sentencing Project, Mauer, 1997). It cannot be determined for sure whether this sentencing disparity is racially motivated. However, African Americans, who are only $13 \%$ of the general population, account for $39 \%$ of crack cocaine users, but $89 \%$ of those sentenced for federal crack crimes (Coalition for Federal Sentencing Reform, 1999). Media portrayals of cocaine use reinforce the stereotype that crack is a "black drug" (Reeves \& Campbell, 1994). Crack babies and other harms associated with crack cocaine were so broadly portrayed and discussed when the law was originally proposed and debated (Kennedy, 1997), that not a single African American 
Congress member spoke out against the sentencing disparities between crack and powder cocaine.

\section{Corrections}

The end result of biases created by myths inherent within the criminal law, reinforced in the criminal justice system, and portrayed by the media is our corrections system. The increased use of incarceration in the United States (Beck, 1998) has made it the second highest rate of incarceration in the world, behind Russia. The incarceration rate is at least five times greater than most industrialized nations. Because most convicted criminals never serve a day in a correctional facility, probation and parole populations have grown to more than 5 million (Mauer, 1997).

Incarceration is one of the most serious sanctions available within American sentencing options. The persons arrested and punished are characterized as $94 \%$ male; about $65 \%$ have not completed high school; one third are unemployed; one third earn less than \$5,000 annually; almost $60 \%$ report being under the influence of drugs at the time of their offenses. African American males are incarcerated at a rate 4 to 5 times that of those in South Africa, almost 4,000 per 100,000 (Mauer, 1991, 1992, 1994). In federal prisons, 93\% are male, 39\% are African American, and $30 \%$ are Hispanic. Whereas nearly $60 \%$ of federal prisoners are sentenced for drug crimes, 3\% are sentenced for violent crimes and 6\% for white-collar offenses. The priorities of the U.S. criminal justice system are clear.

Consequently, nearly half of incarcerated people in the United States are African Americans; so, a prison industry is being built "on the backs of blacks" (Blakemore, 1998, p. 4). In fact, there are more African American males incarcerated than enrolled in higher education. In the midst of unprecedented new prison construction, 38 states and Washington, D.C. witnessed an increased racial disparity in incarceration rates from 1988to 1994. The African American rate of incarceration (1,511 per 100,000) is almost 8 times as great as the rate of incarceration for Whites (193 per 100,000) (U.S. Department of Justice, 1997). In 1970, there were 133,000 African Americans in prisons and jails, but in the year 2000, it is expected that the number will increase to almost 1.1million,a $780 \%$ increase. In 1950, African Americans made up about 35\% of state and federal prisoners, but in the year 20I 0, it is expected that they will account for about 68\% (National Center on Institutions and Alternatives, 1999a). The greatest increase in incarceration between 1989 and 1994 was 78\% for African American women (Mauer \& Huling, 1995). From 1986 to 1991, the number of African American women incarcerated for drug offenses in state prisons increased $828 \%$ (Mauer \& 
Huling, 1995). More African American women are being incarcerated partly because they do not have anything to offer the prosecutors, who are looking for "bigger fish," and so the "small fish" in the drug markets go to prison (Miller, 1997).

The result of such disparities is apparent. For example, 1 in 7 African Americans cannot vote because of felony convictions (Mauer, 1997). Almost 80\% of African American males can expect to be arrested by the time they reach age 35 (National Center on Institutions and Alternatives, 1999a; also see Miller \& Holman, 1992; Tillman, 1987). Although 1 in 3 African American males are involved in the criminal justice system, only 1 in 15 young White males and 1 in 8 Hispanic males are so involved (Mauer, 1997). African Americans make up 3\% of California's population, but $40 \%$ of its state's inmates (Miller, 1997,p. 28). Miller claims that contact with the criminal justice system is now a "rite of passage" for young African American men, and as a result,

\begin{abstract}
it is now a sad reality that most of the young black men can anticipate being at least briefly ushered through a series of hothouses for sociopathy: prisons, jails, detention centers, and reform schools-all of which nurture those very characteristics that can subsequently be labeled as pathological.
\end{abstract}

Blakemore (1998, p. 5) calls contact with the criminal justice system a "badge of honor" for some African American males and claims punishment loses its deterrent effect for them. Furthermore, criminal justice system targeting of minorities exacerbates problems such as single parenthood and unemployment (Blakemore, 1998).

Incarceration in America costs more than $\$ 20$ billion annually, with more than 11 million new admissions each year (National Center on Institutions and Alternatives, 1999a).For every inmate that gets incarcerated at a cost of $\$ 23,000$ per year, the cost per inmate is equivalent to the tax burden of four American families (Coalition for Federal Sentencing Reform, 1997). Operating the entire criminal justice system costs more than $\$ 100$ billion annually (National Center on Institutions and Alternatives, 1999a). In the 1980 s, federal justice spending overall increased by $668 \%$, county justice spending increased by $711 \%$, and state spending increased by $848 \%$ (Miller, 1997). When these numbers are disaggregated, federal, state, and local expenditures grew $416 \%$ for police, $585 \%$ for courts, $1,019 \%$ for prosecution and legal services, 1,255\% for public defenders, and $986 \%$ for corrections. Between 1900 and 1980, 41 prisons were built, but to accommodate new correctional clients, 38 federal prisons were built between 1980 and 1995, and 10more federal prisons are currently under construction. The correctional population 
exploded from 24,000 in 1980to 118,000 prisoners in 1998. With more complex federal sentencing, federal appeals increased from 225 to 8,731 between 1988 and 1995 . This is not surprising given the growing number of criminal records in the United States today, which is about 50 million, with $60 \%$ of the increase coming in the last decade (Miller, 1997).

Due in part to drugs, 94\% of federal prisoners sentenced and 77\% admitted in 1994 were sentenced for nonviolent crimes. Drug offenders accounted for $36 \%$ of the increases in state prison populations and more than $70 \%$ in federal prison populations from 1985 to 1994 (Families Against Mandatory Minimums, 1999). National prison populations increased 52\% for violent criminals but 156\% for drug offenders between 1988 and 1994 (Mauer, 1997). The number of African Americans in state prison for drug offenses increased $466 \%$ (Mauer, 1997)compared to a $106 \%$ for White males between 1986 and 1991 (Mauer, 1997).In 1992, the federal system had 12,727 nonviolent, low-level drug offenders with no criminal history, serving an average time of 6 years (U.S. Department of Justice, 1994). Today, nonviolent, low-level drug offenders make up more than $21 \%$ of total federal prison populations (National Center on Institutions and Alternatives, 1999a). Figure 2 shows drug offenders as a percentage of all offenders sentenced to federal prisons. There has been a dramatic increase in drug offender imprisonment, with drug offenders comprising $60 \%$ of all federal inmates (Federal Bureau of Prisons, 1998). It is the same at the state level with more than $50 \%$ of state prison inmates convicted of crimes that are considered petty by the American public (Irwin \& Austin, 1994).

Although disparities in the corrections system appear to be based on race, social class also plays a significant role. This is because the poor are disproportionately minorities. In 1997, African Americans made up almost $26 \%$ of all people living in poverty compared to $46 \%$ for Whites and $22 \%$ for Hispanics (U.S. Census, 1999). There are more poor Whites in the United States, but the rate of poverty is higher for African Americans who account for only $13 \%$ of the general population. Meanwhile, $24 \%$ of African American families live in poverty compared to $25 \%$ of Hispanic families and 8\% of White families. Although the 1997 median income for African American families was \$25,050, \$26,628 for Hispanics, and \$38,972 for Whites, the per capita income for African Americans was \$12,351, $\$ 10,773$ for Hispanics, and $\$ 20,425$ for Whites (U.S. Census, 1999). Given the intimate connections between social class and race, social class also appears to play a major role in criminal justice system mythology and bias (Chambers, 1995; Headley, 1991). Being a minority and poor is thus a double encumbrance, resulting in a much greater probability of being processed through the criminal justice system despite being no more criminal than middle-class Whites. 


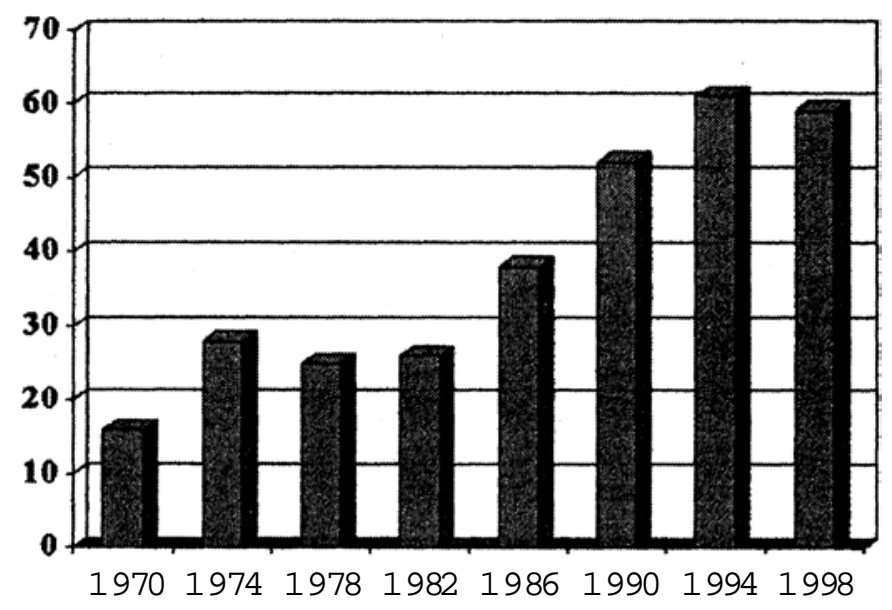

Figure 2: Drug Offenders as Percentage of All Offenders Sentenced to Federal Prisons

\section{CONCLUSION}

This article demonstrated how myths of race and crime are created and reinforced through criminal justice and media processes. The sad result of this myth process is that African Americans suffer the greatest harms at the hands of the criminal justice system. The reasons include the following: legislators are not representative of the general population; voters elect law makers who are not representative of the general population; the lawmaking process is driven by donations made by powerful corporations and lobbies in efforts to protect their financial interests and prevent their acts from being legislated as crimes; crimes of the poor are viewed as greater threats by politicians and members of society, thereby creating a bias in the criminal law against these groups; African Americans are disproportionately poor; the poor have fewer resources to fight the criminal justice system; police are located in areas where greater numbers of poor and minorities reside; police target and profile African Americans for arrests; certain crimes perceived as Black crimes are subject to special sentencing laws; prosecutors have almost unlimited power in the use and abuse of discretion in charging accused suspects and in recommending criminal sanctions; and African Americans are inhibited from serving on juries. These processes are reinforced by the stereotype of a criminal as a young, poor, minority male from the inner city; this stereotype is portrayed in the news and on television crime entertainment shows. 
This process creates myths of race and crime. Myth 1: The label of crime is a function of what is most harmful to society; Myth 2: African Americans commit more crime than other groups in society; and Myth 3: The criminal justice system is fair or unbiased. Understanding that these myths are not truths demands a closer examination of the overrepresentation of African Americans and other minorities in the criminal justice system by questioning the myth that their overrepresentation results from their criminal behaviors and the resulting harms. A result of these myths of race and crime is that over-all racial disparities in the criminal justice system are worse today in the post-civil rights era. "As the majority of faces in prison become black or brown (and as) sentencing policies become more rigid, punitive, and vicious ... the country's historic policy of segregation is being replaced by a policy of incarceration for a substantial proportion of the black male population" (Holman, 1999). In other words, because of deeply entrenched myths that are reinforced by criminal justice system processing and media coverage and reporting activities, the American system of criminal justice has engaged in a new form of racial segregation: punishment.

\section{REFERENCES}

Akers, R. ( 1996). Criminological theories: Introduction and evaluation. Los Angeles: Roxbury.

Beck, A. (1998). Trends in U.S. correctional populations: Why has the number of offenders under supervision tripled since 1980? In K. Haas \& G Alpert (Eds.), The dilemmas of corrections. Prospect Heights: Waveland.

Bernard, T. (1983). The Consensus-conflict debate: Form and content in social theories. New York: Columbia University Press.

Blakemore, E. (1998). The effect of mandatory minimum sentencing on Black males and Black communities [On-line], Available: 222.udayton.edu/-race/annotate/ s98blake.htm (Retrieved February 19, 1999)

Bohm, R. (1986). Crime, criminal and crime control policy myths. Justice Quarterly 3(2), 193-214.

Brunk, G, \& Wilson, L. (1991). Interest groups and criminal behavior. Journal of Research in Crime and Delinquency, 28, 157-173.

Catellano, T., \& McGarrell, E. (1991). The politics of law and order: Case study evidence for the conflict model of the criminal law formation process. Journal of Research in Crime and Delinquency, 28, 304-329.

Centerwall, B.(1992). Television violence: The scale of the problem and where to go from here. Journal of the American Medical Association, 267(22), 3059-3062.

Chaffee, R. \& German, D.(1998). New frontiers in political socialization research. In K. P. R u fer and W. Birgi t (Eds.), Sozialwissenschaftliche und bildungstheoretische Reflexionen: fachliche und didaktische Perspektiven zur politisch-gesellschaftlichen Aujklarung. Cambridge: Galda and Wilch Verlag. 
Chambers, J. (1995). Blacks and crime: A function of class. Westport, CT: Praeger.

Chambliss, W., \&, Seidman, R. (1971). Law, order, and power. Reading, MA: Addison-Wesley.

Chambliss, W. \& Seidman, R. (1982). Law, order, andpower (2nd ed). Reading, MA: Addison- Wesley.

Chiricos, T. (1991). Unemployment and punishment: An empirical assessment. Criminology, 29, 701-724.

Chiricos, T.(1995). Moral panic as ideology: Race, drugs and prisons in the United States. In M. Lynch and E. B. Patterson (Eds.), Race and criminal justice: A further look. New York: Harrow and Heston.

Coalitionfor Sentencing Reform. (1997). Fact sheet on the U.S. federal justice system [On-line]. Available: www.sentencing.org/facts.html (Retrieved February 17, 1999)

Coalitionfor Sentencing Reform. (1999). [On-line]. Available: www.sentencing.org/ facts.html

Cohen, J., \& Solomon, N. (1994). "Crime time" news exploits fears. Indianapolis Business Journal, 15(13), 6.

Cole, D. (1999). No equal justice : Race and class in the American criminal justice system. New York: New Press.

Cole, G., \& Smith, C. (1998). The American system of criminal justice. Belmont: Wadsworth.

Common Cause. (1999) [On-line]. Available: www.commoncause.org/laundromat/ results.html (Retrieved February 23, 1999)

Congressional Quarterly.(1999, January 9). New Congress is older, more politically seasoned, (pp. 60-63).

Culverson, D. (1998). Stereotyping by politicians: The welfare queen and Willie Horton. In C. R. Mann and M. Zatz (Eds.), Images of color, images of crime. Los Angeles: Roxbury.

DeLouth, T. N., \& Woods, C. (1996). Biases against minorities in newspaper reports of crime, Psychological Reports, 79(2), 545-546.

Denzinger, S. (1996). The real war on crime: The report of the national criminal justice commission. New York: HarperPerennial.

Elliott, D., \& Ageton, S. (1980). Reconciling race and class differences in selfreported and official estimates of delinquency. American Sociological Review, 45, 95-110.

Eubanks, W. (1987). The myth of a racist criminal justice system. Monterey: Brooks/ Cole.

Families Against Mandatory Minimums. (1999). [On-line]. Available: www.famm. org (Retrieved February 23, 1999)

Federal Bureau of Prisons (1998). Federal Bureau of Prisons Quick Facts [On-line]. Available: www.bop/gov (Retrieved February 17, 1999)

Frank, N., \& Lynch, M. (1992). Corporate crime, corporate violence: a primer. New York: Harrow and Heston.

Friedrichs, D. (1995). Trusted criminals: White collar crime in contemporary society. Belmont, CA: Wadsworth. 
Fukurai, H., Butler, E., \& Krooth, R. (1993). Race and the jury: Racial disenfranchisement and the search for justice. New York: Plenum.

Gaynes, E. (1993). The urban criminal justice system: Where young + Black + male = probable cause. Fordham Urban Law Journal , 20, 621.

Hagan, J. (1989). Why is there so little criminal justice theory? Neglected macro- and micro-level Jinks between organizations and power. Journal of Research in Crime and Delinquency, 26, 116-135.

Headley, B. D. (1991). Race, class and powerlessness in world economy. Black Scholar, 21(3), 14-21.

Hindelang, M., Hirschi, T., \& Weis, J. (1980). Measuring delinquency. Beverly Hills, CA: Sage.

Hollinger, R., \& Lanza-Kaduce, L. (1988). The process of criminalization : The case of computer crime Jaw. Criminology, 26, 101-126.

Holman, B.(1999). Myth of the month-January 1999: What happened to the dream? National Center on Institutions and Alternatives [On-line]. Available: www. igc.org/ncia/

Hurwitz, J., \& Peffley, M. (1997). Public perceptions of race and crime: The role of racial stereotypes. American Journal of Political Science, 41(2), 375-401.

Irwin, J., \& Austin, J. (1994). It's about time: America's imprisonment binge. Belmont, CA: Wadsworth.

Jackson, P. (1997). Minority group threat, crime and policing : Social context and social control. New York: Praeger.

Joint Center for Political and Economic Studies (1993). Black elected officials: A national roster. Washington, DC

Kappeler, V., Blumberg, M., \& Potter, G. (1996). The mythology of crime and criminal justice. Prospect Heights: Waveland.

Kennedy, R. (1997). Race, crime and the law. New York: Vintage.

Kooistra, P., \& Mahoney, Jr., J. (1999). The historical roots of tabloid t.v. crime. In J.Farrell \&N. Websdale (Eds.), Making trouble: Cultural constructions of crime, deviance, and control. Hawthorne, NY: Aldine.

Livingston, J. (1994). Crime and the media: Myths and reality. USA Today Magazine /22(2588), 40-42.

Mann, C. (1993). Unequal justice. Bloomington: Indiana University Press.

Marsh, H. (1991). A comparative analysis of crime coverage in newspapers in the United States and other countries from 1960-1989: A review of the literature. Journal of Criminal Justice, 19(4), 67-79.

Mauer, M. (1991). Americans behind bars: A comparison of international rates of incarceration. Report by The Sentencing Project.

Mauer, M.(1992).Americans behind bars: One year later. Report by The Sentencing Project.

Mauer, M. (1994). Americans behind bars: The international use of incarceration, 1992-1993. Report by The Sentencing Project.

Mauer, M. (1997). Intended and unintended consequences: State racial disparities in imprisonment. Report by The Sentencing Project. 
Mauer, M. (1998). "Lock 'em up and throw away the key": African American males and the criminal justice system. In K. Haas \& G Alpert (Eds.), The dilemmas of corrections. Prospect Heights: Waveland.

Mauer, M. \& Huling, T.(1995). Young Black Americans and the criminal justice system: Five years later. Report by The Sentencing Project.

McGarrell, E. (1993). Institutional theory and the stability of a conflict model of the incarceration rate. Justice Quarterly, JO, 7-28.

McGurrin, D., Fenwick, M., \& Lynch, M. (1999). Representing white collar crime: An examination of journal and textbook contents. Paper presented to the annual meeting of the Academy of Criminal Justice Sciences, Orlando, FL.

Meddis, S. (1993, July 27). Drug war claiming "entire generation" of young Blacks. USA Today.

Miethe, T. (1995). Fear and withdrawal from urban life. The Annals of the American Academy of Political and Social Science, 539, 14.

Miller, J.(1997, June). African American males in the criminal justice system. Phi Delta Kappan, 22-30.

Miller, J. \& Holman, B. (1992). Hobbling a generation: African American males in the District of Columbia's criminal justice system. Washington, DC: National Center on Institutions and Alternatives.

National Association of Criminal Defense Lawyers. (1996). Racism in the criminal justice system. Washington, DC.

National Center on Institutions and Alternatives. (1999a). Myth of themonthFebruary 1999 [On-line]. Available: www.ncianet.org/ncia/mythc .html (Retrieved February 16, 1999)

National Center on Institutions and Alternatives. (1996b). What every American should know about the criminal justice system [On-line]. Available:www.ncianet. org/ncia/facts.html (Retrieved February 23, 1999)

National Conference on State Legislators. (1999). Women in state legislatures 1998 [On-line]. Available: www.ncsl.org/programs/legman/about/women.htm (Retrieved February 17, 1999)

Nazario, S. (1993,December 12).Odds grim for Black men in California. Washington Post , p. A-9.

Newman, G. (1990). Popular culture and criminal justice: A preliminary analysis. Journal of Criminal Justice, 18, 261.

Pope, C. (1979). Race and crime revisited. Crime and Delinquency, 25 (3), 347-357.

Quinney, R. (1969). The social reality of crime. Boston: Little, Brown.

Quinney, R. (1970). The problem of crime. New York: Dodd, Mead \& Company.

Reed, I. (1993). It's racist. American Journalism Review, 15, 7 and 22-23.

Reeves, J., \& Campbell, R. (1994). Cracked coverage: television news, the anticocaine crusade, and the Reagan legacy. Durham, NC: Duke University Press.

Reiman, J. (1996). The rich get richer and the poor get prison. Boston: Allyn and Bacon.

Roberts, D. (1993). Crime, race and reproduction. Tulane Law Review, 1945. 
Robinson, M. (1994). Environmental characteristics associated with residential burglaries of private student apartment complexes. Master's thesis, The Florida State University, Tallahassee.

Robinson, M. (1998). Tobacco: The greatest crime in world history? The Critical Criminologist 8(3), 20-22.

Robinson, M. (1999). What you don't know can hurt you: Perceptions and misconceptions of harmful behaviors among criminology and criminal justice students. Western Criminology Review, 2, 1 [On-line]. Available: wcr.sonoma.edu/v2nl/v2nl.html

Rome, D. (1998). Stereotyping by the media: Murderers, rapists, and drug addicts. In C. R. Mann \& M. Zatz (Eds.), Images of color, images of crime. Los Angeles: Roxbury.

Rosoff, S., Pontell, H., \& Tillman, R. (1998). Profit without honor: White-collar crime and the looting of America. Upper Saddle River: Prentice Hall.

Salant, J. (1999). Tobacco giant Philip Morris tops list of political contributors [On-line]. Available: www.nandonet.com (Retrieved February 22, 1999)

Simon, D., \& Eitzen, S. (1993). Elite deviance. Boston: Allyn and Bacon.

Simon, D., \& Hagan, F.(1999). White-collar deviance. Boston: Allyn and Bacon.

Skogan, W. (1995). Crime and the racial fears of White Americans. Annals of the American Academy of Political and Social Science, 539, 59-71.

Skolnick, J. (1998a). The color line of punishment. Michigan Law Review, 96 (6), 1474-1485.

Skolnick, J. (1998b). The color of the law. American Prospect, 39, 90-95.

Smith, P.(1990).Felony defendants in large urban counties, 1990. Washington, DC: Bureau of Justice Statistics.

St. John, C., \& Heald-Moore, T. (1996). Racial prejudice and fear of criminal victimization by strangers in public settings. Sociological Inquiry, 66(3),267284.

Sutherland, E. (1977a). Is "white-collar crime" crime? In G. Geis \& R. Meier (Eds.), White-collar crime: Offenses in business, politics, and the professions. New York: Free Press.

Sutherland, E. (1977b). White-collar criminality. In G. Geis \& R. Meier (Eds.), White-collar crime: Offenses in business, politics, and the professions. New York: Free Press.

Thornberry, T. \& Farnworth, M. (1982). Social correlates of criminal involvement. American Sociological Review, 47, 505-517.

Tillman, R. (1987, Fall). The size of the "criminal population":The prevalence and incidence of adult arrests. Criminology, 335-347.

Tittle, C., \& Meier, R. (1990). Specifying the ses/delinquency relationship .Criminology, 28, 271-299.

Tittle, C., \& Villemez, W. (1977). Social class and criminality. Social Forces, 56, 474-503.

Tittle, C., Villemez, W., \& Smith, D.(1978). The myth of social class and criminality: An empirical assessment of the empirical evidence. American Sociological Review, 43, 643-656. 
Tonry, M. (1995). Malign neglect..Race, crime and punishment in America. Oxford University Press.

Tunnell, K. (1992). Film at eleven: Recent developments in the commodification of crime. Sociological Spectrum, 12, 293-313.

U.S. Census. (1996). Characteristics of the voting-age population reported having registered or voted: November 1994 [On-line]. Available: www.census.gov (Retrieved February 23, 1999)

U.S. Census. (1999). Poverty in the United States: 1997 [On-line]. Available: www. census.gov (Retrieved February 19, 1999)

U.S. Department of Justice. (1987). The prosecution of felony arrests. Washington, DC: Author.

U.S. Department of Justice. (1994). Sourcebook of criminal justice statistics . Washington, DC: Author.

U.S. Department of Justice. ( 1997). Sourcebook of criminal justice statistics. Washington, DC: Author.

U.S. Sentencing Commission. (1995). Special report to the congress: Cocaine and federal sentencing policy. Washington,DC: Author.

Vold, G (1958). Theoretical criminology. New York: Oxford University Press.

Walker, S., Spohn, C., \& Delone, M. (1996). The color of justice:Race, ethnicityand crime in America. Belmont,CA: Wadsworth.

Washington Post (1983, January 11). P. CIO.

Weisburd, D., \& Schlegel, K. (1992). Returning to the mainstream: Reflections on past and future white-collar crime study. In K. Schlegel \& D. Weisburd (Eds.), White-collar crime: Offenses in business, politics, and the professions. Boston: Northeastern University Press.

Woo, L. (1994, April). Today's legislators: Who they are and why they run. State Legislatures, 28-33.

Wright, R. (1993). A socially sensitive criminal justice system. In J. Murphy \& D. Peck (Eds.). Open institutions: The hope for democracy. Westport, CT:Praeger.

Matthew Robinson is an assistant professor of criminal justice at Appalachian State University in North Carolina. His research focuses primarily on criminological theory, criminal victimization, crime prevention, and criminal justice education. His most recent publications appear in the British Journal of Criminology, Journal of Crime and Justice, the Advances in Criminological Theory series, Journal of Security Administration, International Journal of Risk, Security, and Crime Prevention, and Environment and Behavior. 